\title{
Translation: A Case of Border Crossing in the Global Village
}

Maya Pandit

Translation is a journey that requires the translator to cross many borders. The text being translated is not an incommensurable universe; it is part of a landscape that gets mapped in the dynamic and complex relationship defined by the constitutive and constituent forces operating in specific social formations at particular points in time. The text itself may provide perspectives on the way the terrain should be negotiated, navigated, and traversed. The task becomes all the more difficult when one realizes that the paths have to be constructed for an outsider, a traveler who may be entirely new to the peninsula and needs to be introduced to the region, to the nooks and corners of this territory, since this is basically what a translator is expected to do. The boundaries of this terrain keep on shifting according to the preoccupations of the translator / reader, the general political cultural ethos, and the intentionality of the original author and that of the translator. The receiver/s of translations are also located in contexts that are fraught with various tensions as they represent the site of multiple struggles. So the translator's ideas about the roadmap of expectations that the receiver may have in mind and the actual lampposts that emerge through his/her act of translation, also play a significant role in the act of translation.

Besides, the relationship between languages and cultures is complex. Languages do not simply reflect reality; they obfuscate it at times. They may even hide reality of exploitation, inequalities or various asymmetries in favour of certain normative perceptions that are privileged in the society. In this sense, the contexts may represent vibrant political, linguistic or cultural struggles, which are glossed over or obliterated by the dominant users of language. They draw boundaries between the 'included' and the 'excluded', between what is politically expedient from the perspective of a particular dominant group and what is not. It is possible that the translator translating a text from his/her own language is sometimes rudely awakened out of his/her self-proclaimed familiarity with the 
terrain in unexpected ways in the act of negotiating the roadmap. $\mathrm{S} / \mathrm{he}$ has to be aware of the obvious routes and the escape routes; the main roads and the hidden paths and the difficulties involved or the traps they set in for the translator. At least that is what I have discovered while translating literature from Marathi into English. I would like to share some of these preoccupations with you in order to discuss a few of the problems encountered in crossing many boundaries, visible and invisible, in the act of translation.

The problems begin with the very decision to translate Marathi texts into English. Why English? Why not some other language? Who does one translate for? And why? What is the impact one strives for? Who is the readership? Is it an "assorted generation of asylum seekers who want to belong to the elite English club" as Rita Kothari has noted?

Before answering these questions it is worthwhile looking at the relationship between globalization and English. The foundations of the expansion of the English language outside the Englishspeaking world were laid as the British empire itself expanded after 1600. With the historical legacies of imperialism and capitalistic development, English did indeed spread almost all over the world. The proportions of the spread of English today, however, are phenomenal. The scope of globalization and the energies unleashed by it all over the world are absolutely unprecedented in the history of the world. (It must be remembered here that more than forty per cent of the world's population is illiterate.)

It is possible to consider globalization as the extension of, and the later stage in, the development of linguistic imperialism that has dominated the third world for the last three hundred odd years. As Mignolo points out in his insightful essay on the relationship that obtains between globalization and various subordinated cultures, (Mignolo 1998), linguistic imperialism, under its 'civilizing mission', was a project to extend the imperial plan of collecting and configuring knowledge in terms of western frames of reference. In so doing, it systematically denied 'local' knowledge of the 'natives' any epistemological possibility or 
acceptability under its 'civilizing mission'. The dichotomy between the eastern / local and the western / global was also in a sense synonymous with the dichotomy between 'culture' and 'civilization'. Unless something was articulated in western discourse fields, such as education, and in languages acceptable to it, such as English, German, or French, it was not considered 'civilized knowledge'. As a result what constituted knowledge for the local was considered imperfect, archaic, irrelevant, pre-modern and at times even unscientific and wrong. An attempt was therefore consciously undertaken in many colonies of the European countries to "improve" the local cultures, as well as languages, with the advanced knowledge of the "civilized" countries of the colonial rulers. This is reflected in the process in which, initially, third world cultures came to be characterized as 'barbaric'; then they became 'exotic' and were studied from an anthropological perspective to underline their difference from the civilized countries of Europe first and America later.

The two major domains in which this difference was addressed and established were language and literature. English language and literature became the major tools for achieving this aim. The disciplinary foundations of English literature and English language were laid in India and in many third world countries in this respect during the earlier phases of imperialism. And very cleverly the consent of the native elite - in the case of India, the upper caste Brahmins and the powerful landlords - was obtained in this endeavour. Lord Elphinstone, the Governor of Mumbai, declared in 1824 that the task of the European rulers was to conciliate the elites - the upper castes - in Indian society to their rule, in their project of 'grafting' the advanced knowledge of the European civilization on the underdeveloped Indian languages. That was in response to the need of the expanding market, to use Macaulay's words, "to sell our glasses and cutlery to the Indians". The important point was that it was translation that was defined as the methodology of that grafting. This went a long way towards laying the foundations of translation from English into the local languages, and translation achieved a great importance and cultural significance in constructing an orient as well as various knowledge 
fields that carried an imprint of the dominance of the western world on the one hand and of the upper class, upper caste native elites on the other (as represented for instance by the translations from Sanskrit).

In today's world, as David Graddol claims in English Next, "English is a phenomenon that lies at the heart of globalization; English is now re-defining national and individual identities worldwide, shifting political fault lines, creating new global patterns of wealth and social exclusion; and suggesting new notions of human rights and responsibilities of citizenship" and goes on to declare that "the world English project is under way" (2005: 12).

One may look at the overall linguistic scenario of the present world in this context as pointed out by David Crystal (Crystal 1997). Of the literally thousands of languages in the world, one hundred account for 95 per cent of the world's population, the remaining 5 per cent speaking those thousands of other languages that remain ignored and that eventually may even die and disappear from the face of the world. Of the one hundred languages, twelve are spoken by 75 per cent of the population of the world. Of these, six are colonial and languages of European modernity. Their ranking by number of speakers is: English, Spanish, German, Portuguese, French, and Italian. In fact, Chinese has a greater number of speakers than English, and Hindi occupies a place between German and Russian. The number of speakers of Arabic and Bengali exceeds that of French, Portuguese, and Italian. Yet the European languages are considered to be the languages of scholarship in the domains of knowledge, intellectual production, and the cultures of scholarship. English is claimed to be a world lingua franca, a universal language of knowledge used by around 337 million people as their first language and by over thirty-five crore people, all over the world, as a second, or additional, language, in countries such as India, Pakistan, Sri Lanka, Nigeria, and the Philippines, as well as in many others. In addition, an additional 1.5 crore people are learning it, in China, Japan, Malaysia, and the Philippines. The United States, the world's largest English speaking nation, has only about twenty per 
cent of the world's English users and the United Kingdom, about five per cent (Krishnaswami and Krishnaswami 2006).

In addition to its connection to imperialism, English has also been a tool of domination and oppression in the hands of the urban elite, who are marked by increasingly consumerist tendencies. It has been emerging all over the world as the language of international communication. Harish Trivedi has described this spread as the 'cultural totalitarianism' represented by English (Trivedi 1996).

All of these facts - historical, political, linguistic and cultural- have a bearing on the activity of translation and the translation cultures that have emerged in India. This poses a major challenge to the translator: what should be translated; which direction the traffic of translation should take; which language should be a source language and which language a target language? Should we translate from one Indian language into another? Or should we give primacy to translations from English and other 'developed' languages into our Indian languages?

For me as a translator, the problem cannot be posed as an either-or problem. Against the background of internal colonization by the urban upper caste middle class elite of the subordinated local sub-cultures, it might be politically more expedient to translate resistance writing from the local languages into English, as well as from one Indian language to another. Dalit writing is a case in point. This body of writing is produced by people from the margins of society who have long been dominated by the upper class and upper castes. The history of their resistance and struggle for release from the age old bondage is very important because it has extended the frontiers of existing knowledge domains, as well as released energies for the liberation of downtrodden people from many areas (Zelliot 1992). Should it be translated only into the other Indian languages of similarly deprived and oppressed sections of other societies? On the other hand, in the days of globalization, is it possible to start a process of 'reverse swing', having an exactly opposite direction of influence? In the past English was used as a tool for the exclusion of 
the lower caste from the domains of knowledge. Now English can be appropriated and used as a tool of assertion of the identities of the oppressed and marginalized, as well as for constituting new domains of knowledge. Rather than argue, along the lines of Kothari (2006: $34)$, that the situation is neither one of 'confrontational neutrality' nor of 'unequivocal totalitarianism', it possible to take a more assertive stand. Also what is from the margins in the regional language and culture can be brought into forefront of the international arena for the sake of bonding with similar cultural forces operating within other cultures. Given the spread and significance of the English language, the English translation could then be a form of radical intervention in the dominant literarycultural-political discourses in these other cultures.

When Daya Pawar, the first major Dalit writer, wrote and published his autobiography, Baluta, there was a strong reaction from many sections of Marathi society, including Dalits, that the story of the sufferings of the Dalits was being written for a middle class Brahminical readership by a Dalit who typically cast himself into the victim mode. And yet the autobiographical writing by Daya Pawar represented a crossing of the boundaries in many senses of the term. This was a crossing of the boundary that divided the 'impure' from the 'pure', the 'sacred' from the 'profane' and the lower strata of the society from the elite within Marathi culture. This act of writing by a Dalit of his community's suffering itself represented an act of transgression. This writing represented a crossing of the boundaries, from the margins of Marathi literary culture into the mainstream of Marathi literature itself. The act had thus become controversial for various reasons. But then Pawar's writing managed to break the stranglehold of the dominant universalist aesthetics in Marathi through his radical act of self assertion in the language of his own caste, class and community. The book challenged the notion of universal brotherhood as well the dominant aesthetics of high caste Marathi language. Many Dalit books followed Baluta and these Dalit articulations, which had once occupied a place on the margins of Marathi cultural production, have today come to occupy almost the central place in it. For the 
translator, thus, Dalit writing poses an interesting set of challenges on the cultural and political level within India itself.

The issue has now entered the terrain of international struggles. There is now a strong debate going on with respect to the similarities between Caste and Race issues since the Durban Conference on Race and the same logic can be extended to the specificities and differences of the struggles of the other minorities in order to bring out the similarities among the factors that constitute these differences, as well the strategies of resistance. Taking the life histories of the marginalized to an international scale in order to form bonds with similarly oppressed sections of various societies becomes a political form of action for a translator. And it is here that the significance of English as the dominant language needs to be appropriated. When, for instance, I realized that Baby Kamble's Jina Amucha had been already translated into some other Indian languages and even Spanish, I decided that an English translation was a must. The necessity of aligning with radical forces from other regions, societies, and cultures, constantly fighting to change the world, proved to be far stronger than the so-called lure of the prestige of English. Political commitment can become the defining force behind translations in cases such as these. Consider, for instance, the autobiographies of Dalit women and women's testimonios from Spanish-speaking Latin American countries! Rigoberta Manchu, the Nobel award winner Guatemalan writer, wrote about the civil war and the sufferings of indigenous people there. Rigoberta helps us understand their suffering, which is different from anything we have known; but at the same time the excesses of the imperialist oppression, the human bonds that common, suffering people form with each other and their resistance is something that links them with us. As Rege argues (Rege 2006), Dalit writing is different as it talks about suffering which is distinctively different, like the suffering that comes across to us in the Spanish testimonies. This is not merely to celebrate the 'difference' of the Dalit communities, but to explicate the factors that bring this 'difference' into existence, in the form of a life based upon indignities and humiliation, in order to challenge and change it. 
That is what links the Spanish testimonies with Dalit writing, for instance. And taking such writing to a wider set of people, involved in similar struggles, in order to build bridges of understanding between the different manifestations of resistance, becomes significant.

This signifies that the role of the translator is far more transgressive than is envisaged by many translation theorists. According to Anthony Pym, for instance:

Translation is generally considered to be a woman's field. It's seen as one of the 'nurturing' professions, professions which care for other people, where the workers' reward is supposed to be the good feeling they have about helping others. Translating is like smiling, or like typing out a dictated letter. It's a nurturing profession. We are supposed to like helping people to communicate with each other, and that's supposed to be our reward. (Pym 1993, 55)

But in the case of the translation of people from the oppressed sections of society, the translator becomes a political agent in disseminating resistance across similarly deprived and suffering communities. Translation nurtures resistance, thereby becoming a subversive act of crossing the boundaries of territories hitherto defined in terms of sacred / profane, pure / polluting, high / low. How does one go about it?

As I have said above, dominant cultures within a society very often suppress the reality of the oppressed and this poses a problem of representation for the translator. The translator has to enter the text and look at the hidden paths and, in some cases, clear out a lot of dead wood in order to bring to light certain domains that lie dormant or hidden in the text, under the linguistic façade. Words then become more complex signifiers which may hint at more than the realities represented. The problem for the translator is how to bring these dormant realities alive through the translation. Various translators tackle this problem in different ways. When I translated 
Baby Kamble's autobiography Jina Amucha, I encountered a similar problem. The title of the original Marathi book meant "This Wretched Life of Ours". But actually the book narrates a heroic tale of the struggle of the entire Mahar community under Dr. Ambedkar's leadership; it is a story of suffering as well as courage, fired by the indomitable will of the women to change the life of the entire community. The collectivity of the struggle and resistance becomes more important. The book is not written in the victim mode. This underlying reality, which is taken from the lived struggle of the Dalits for dignity and self respect and which is not represented in the Marathi title, became more important for me. Hence, I changed the title of the translation from the literal This Wretched Life of Ours to The Prisons We Broke. This may be termed as a 'compensatory' translation strategy, but it at least partially managed to bring alive the political context of the struggle, the self assertion, and the agency of women and their communities.

In the course of her narration, Baby Kamble brings alive a world constituted by a difference in location. The difference is not only in terms of geography, however. Her world is physically located on the margins of the village, but it is also on the margins of the social imaginary: it is alienating and alienated simultaneously, by being cut off from the village as unclean, impure, polluting, and untouchable. The customs, the rituals, the rites, the festivals, the jatras that she describes are indeed a source of unexplored treasure for a sociologist, as Maxine Berntson says in her brief introduction to the Marathi edition. More than that, however, they represent the composite apparatus of Brahminical dominance, maintained through the weave of superstitions, illiteracy, ignorance, and oppressive practices. Baby Kamble debunks this weave of the cultural apparatus in many ways, using the dialect of her community, matching the rhythms, but filling them with a subversive content. And then she uses standard Marathi, highly ornate and politically charged. Translating these variations was indeed a huge problem. For one thing, there are hardly any lexical, syntactic, or semantic structures that matched the force of the dialect used by Baby. I used standard English for translating, but with a Marathi sentence structure with 
short $\mathrm{N}+\mathrm{V}$ constructions that gave the text a singsong jumpy rhythm.

I have not gone into the problems encountered in the translation of the rituals, the jatras, the sacrifices, worship, and other such details in Dalit autobiographies. Many Dalit autobiographies abound in such details, but how can one prevent their being read patronizingly by the cultural elite, the socially dominant, as exotic details of a strange and amusing way of life of people living on another planet, plucking the text out of its historical context? This is a problem of developing a political perspective on translation. And if the translation does not help develop that perspective, as part of an overall strategy, how does one address the task? It is here that the political commitment to the act of translation and the reading of translations becomes important. I am very much aware that these concerns of mine as a translator and the interests of the publication industry may not necessarily match. Indeed, chances are they won't. However, since many publishers of translations - such as Seagull, Stree, Orient Longman, Oxford, Kali for Women, Samya - seem to be interested in translations, there is scope to believe that translation itself might be an activity by which we may cross the many boundaries between cultures.

\section{Works Cited}

Bagul, B. 2004. Dalit Sahitya Aajche Kranti Vidnyan. Aurangabad: Disha Prakashan, Second edition (First edition, 1981).

Bama. 2000. Karakku. Trans. L. Holmstrom, with the same title. Chennai: Macmillan.

Bassnett, S. and H. Trivedi. 2000. Post-Colonial Translation. Theory and Practice. London: Routledge (First edition, 1999).

Bhagat, D. 2001. Wata Palwata. Trans. M. Pandit, as Routes and Escape Routes. In Drama Contemporary: India, ed. E. B. Mee. Baltimore and London: Johns Hopkins University Press. 
Crystal, D. 1997. English as a Global Language. Cambridge: Cambridge University Press.

Kamble, Baby. 2008. Jina Amucha. Trans. M. Pandit, as The Prisons We Broke. Chennai: Orient Black Swan.

Graddol D. 2005. English Next. London: British Council.

Guru, G. 1998. "Understanding the Category Dalit". In Atrophy in Dalit Politics: Intervention 1, ed. G. Guru. Mumbai: Vikas Adhyayan Kendra.

Kothari, R. 2006. Translating India: The Cultural Politics of English Translation. New Delhi: Foundation Books (First edition, 2003).

Krishnaswami, N. and L. Krishnaswami. 2006. The Story of English in India. New Delhi: Foundation Books.

Mignolo, W.D. 1998. "Globalization, Civilization Processes and the Relocation of Languages and Cultures". In The Cultures of Globalization, ed. F. Jameson and M. Miyoshi. Durham and London: Duke University Press, 32-53.

Pawar, U. 2008. Aaydan. Trans. M. Pandit, as The Weave of My Life. Kolkata: Stree.

Pym. A. 1993. Epistemological Problems in Translation and Its Teaching. Calaceit: Caminade.

Rege, S. 2006. writing caste/writing gender: narrating Dalit women's testimonios. New Delhi: Zubaan.

Trivedi, H. 1996. "The Politics of Postcolonial Translation". In Translation: Its Theory and Practice, ed. A. Singh. New Delhi: Creative Books.

Zelliot, E. 1992. From Untouchable to Dalit: Essays on the Ambedkar Movement, New Delhi: Manohar. 